\title{
What drives Success of Learning Management Systems in Sri Lanka: Student Perspective
}

\author{
S M Samarasinghe*, G D T D Chandrasiri \\ Department of Information Technology \\ University of Sri Jayewardenepura \\ Nugegoda, Sri Lanka \\ "Email: Malkanthi [AT] sjp.ac.lk
}

\begin{abstract}
Developments in Information technology has made rapid changes in the traditional teaching and learning methods in organizations, such as higher education institutions. This new method of teaching and learning is enabled mainly through Learning Management Systems. Issues in effective implementation and management of such systems have drawn the attention of many researchers. However, LMS success research still lacks particularly in the Sri Lankan higher education context. Hence, the purpose of this research was to examine the success of e-Learning systems in the Sri Lankan higher education context. The conceptual model was tested by fitting it to data collected from undergraduate students using learning management systems. This was the first study to test a multidimensional e-Learning systems success model (DeLone and McLean's, 2003, IS success model) in the Sri Lankan context. Of the quality dimensions considered, quality of the information/content provided by the system was the most influential. Student satisfaction had the largest effect size on benefits to students. This study provides meaningful insights particularly relevant to e-Learning implementers in higher education in Sri Lanka.
\end{abstract}

Keywords- LMS Success; IS Success; Higher Education

\section{INTRODUCTION}

With the rapid development of Information technology, traditional teaching and learning methods deployed at organizations, such as higher education institutions, are experiencing radical changes in the way they deliver their teaching and the way the students learn. This new way of teaching and learning is enabled mainly through Learning Management Systems (LMS); an application software, such as Moodle or Blackboard, providing basic e-Learning functionality. The emergence of technology-based teaching/learning systems is one of the most significant developments in the context of information systems over the last two decades [1]. The effective use of information technology (IT) in teaching and learning has been viewed as having the potential to improve the quality of learning [2].
According to [3], using LMSs in education has become a new paradigm because of its convenience, reduction of costs, and flexibility. Almost every higher education institution adopts LMSs for administration of their courses [4]. Hence, it is inevitable that higher education institutions use LMSs for course administration, content delivery and for student evaluation. On the other hand, LMSs provide students with anywhere and anytime access to course materials provided through LMS [5]. Besides, with the rapid growth of technology, demand for technology mediated teaching and learning is gaining higher interest among all the higher education institutions in Sri Lanka. Almost all the higher education institutions have introduced technology-mediated learning through Learning Management Systems (LMS). However, e-Learning (Mainly using LMSs) in Sri Lanka is still in the initial levels toward transforming to e-Learning. Thus, it is important to identify the factors that influence the perceptions of students when such systems are integrated in their learning process. Further, the success of such a system depend on its sustainability. It is, therefore, vital importance to understand the determinants of LMS success in the higher education context in Sri Lanka. Accordingly, the current study intends to address the question, what are the determinants of LMS success to narrow the theoretical gap in the higher education context relating to the success of LMSs integrated in the process of student learning.

\section{LITERATURE REVIEW}

According to [6], understanding the dimensions of e-Learning success is essential for the development and delivery of successful e-Learning initiatives and for continuous improvement of existing systems. Rapid growth in the adoption of technology mediated teaching and learning have motivated researchers to study the success of these systems and the issues related to their implementation [6], [7], [8]. Review of literature revealed that studies have attempted to use measures such as user satisfaction, user acceptance, learning effectiveness, and e-Learning continuance intention in assessing e-Learning systems success. In the context of ISs, 
[9] defined information systems success as a favourable or satisfactory result or outcome from the perspective of different stakeholders. On the other hand, [10] emphasised that ISs success is multidimensional, with different dimensions affecting each other. They suggested the dimensions; quality of the system, quality of the information provided by the system, system use, user satisfaction impact on individuals or organisations. They proposed that ISs success studies would be more meaningful if multidimensional measures are used systematically combining individual success dimensions in an appropriate manner to fit into a particular study context.

LMSs are a kind of information systems very powerful which help transform traditional methods of teaching and learning [11]. The success of LMSs depend on its design, its availability and more importantly students' willingness to use the system for their learning effectively. Although there are a large number of attempts by previous researchers to develop and test models of e-Learning systems success, the number of studies representing LMS success as multidimensional is limited and more specifically seldom studied in developing countries, such as in Sri Lanka. Most of the existing studies representing LMS success, devoted themselves to explain LMS success as a single dimension, such as, user satisfaction, user acceptance or academic performance. Further, studies that have considered LMS success as multidimensional were conducted in cultural contexts very different from Sri Lanka. The IS success model has been used as a basis for e-Learning systems success research. In studying LMS success, it refers to the interaction between technologies and human service processes [7].

According to IS success model, net benefits are determined by information system use/intention to use and user satisfaction and use and satisfaction are directly determined by system quality, information and service quality. The [12] Information Systems Success model describe dimensions of IS success. [10] explained IS success as the extent to which a system achieves the goals for which the system was developed. They ultimately developed the multi-dimensional IS success model based on the literature available at that time using the generic constructs to represent a broader range of contexts. The continuous usage and the dominance of IS success model was examined in the review of literature. Though the Delone and McLean IS success model has been used in many different domains, according to the review of literature, comparably much lesser use of it the in e-learning contexts with all its six success dimensions. Most of LMS success studies utilized three quality dimensions from the IS success model to extend other models or developed new models including other constructs.

Thus, in this study, [12] IS success model was used in defining a multidimensional model as it employs multiple success dimensions in a single model representing the important facets of the success of a system as a whole with the intention to provide a holistic picture of LMS success. As this model combines multiple success dimensions it would be more relevant for a broad range of decision making, rather than identifying a single specific construct. Besides, the model represents as multidimensional is not because of the number of constructs included in the model, but to provide different facets of success with the intention to provide the overall image. Although there were a number of attempts to formulate and validate multidimensional models of e-Learning systems success based on the [12] IS success model, to the researcher's knowledge there were no empirical studies involving multidimensional models of e-Learning systems success conducted in Sri Lanka. Thus, based on the above justification, in the current study the IS success model was further validated in e-Learning domain and in the context of a developing country. The conceptual model used in this study is illustrated in Fig.1. Section 3 explains and justify each predicted relationship in the model, based on the previous findings in literature.

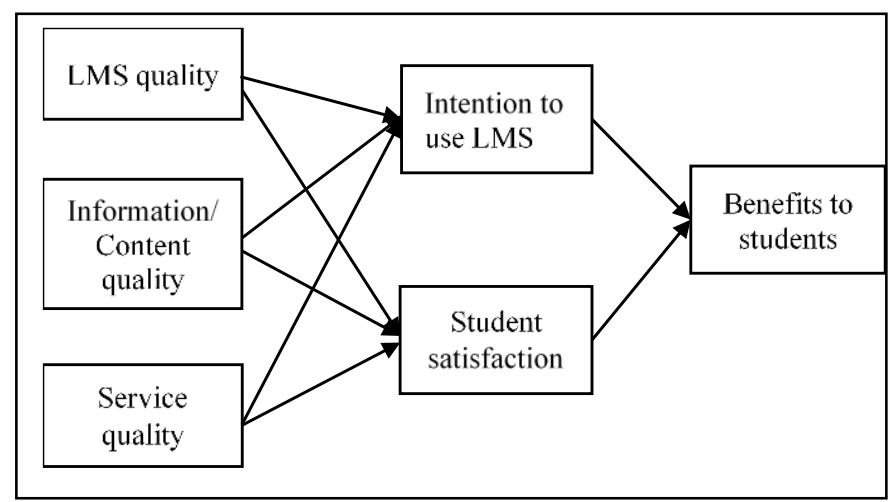

Figure 1:Research Model used in this study

\section{HYPOTHESES OF THE STUDY}

\section{A. System quality affects Intention to use and Student satisfaction}

User satisfaction has been often considered in IS success research [10], [12], [13]. Quality of a system is referred to as the overall performance of a system, namely, hardware, software, network connections, and the user interface of the system [14]. The well-established [12] IS success model suggests that information quality and system quality affect system use and user satisfaction. The TAM model [15] suggested that easy to use systems develop positive user attitudes towards using the system. User of a computerised student information system demonstrated that system quality affects system usage and user satisfaction [14]. In the eLearning domain, similar relationships were established. Prior research evidence suggests that system quality affects eLearning user satisfaction [16], [17], [13]. Further, some other studies found that when the quality and the reliability of the 
system is high, the learner satisfaction would be high [18]. Thus, the following hypotheses are formulated:

\section{H1: System quality has a positive effect on intention to use} LMS.

H2: System quality has a positive effect on learner satisfaction with LMS.

\section{B. Information quality affects Intention to use and Student satisfaction}

Overall quality of a system refers to system quality, information quality and service quality. In the IS context, information quality refers to measures of system output; the quality of the information system produces mainly in the form of reports for decision making. Accordingly, information quality includes primarily the accuracy, reliability, completeness, timeliness, and format [19]. [10] model emphasized that, higher levels of information quality lead to higher levels of user satisfaction and system use, and this relationship was supported by subsequent studies [20], [14]. Moreover, a number of e-Learning systems success studies suggested a positive effect of information quality on student satisfaction and system use [21], [7]. In e-Learning studies, operationalization of information quality is somewhat different. The main objective of a course site is to provide learning related information for students. Thus, information quality primarily refers to information accuracy, completeness, relevance, content needs, and timeliness [1]. [22] found that information quality affects user satisfaction and system use. Information quality as a determinant of user satisfaction [23] and system use have been further confirmed by other studies [24]. Thus, the following hypotheses are formulated:

\section{H3: Information quality has a positive effect on intention to use LMS.}

H4: Information quality has a positive effect on learner satisfaction with LMS.

\section{Service quality affects Intention to use and Student satisfaction}

Service quality can be defined as the difference between customer expectations of the service and their perceptions of the service performance [25]. The importance of the service quality construct in determining the success of different types of ISs is well established [26], [27]. Recognising the importance of service quality in ISs, [12] updated the IS success model to include service quality as a determinant of system use and user satisfaction. In an e-Learning environment, the role of the lecturer is very important [27]. Role of a lecturer could be easily compared to that of a service provider ((such as providing content promptly, giving timely feedback) in any organisation. Further, LMS administrator or the technical staff becomes very vital in helping with technical difficulties faced by students in a technology mediated teaching environment [27]. Support provided by the lecturer and the staff is an important determinant of e-Learning system use by the students [28]. Moreover, timely response from lecturers is important for student satisfaction [22], [13]. [7] emphasised the importance of learner support provided by both lecturers and the IT support staff. Thus, the following hypotheses are formulated:

\section{H5: System quality has a positive effect on intention to use LMS. \\ H6: System quality has a positive effect on learner satisfaction with LMS.}

\section{Intention to use affects Individual benefits}

The benefits are the extent to which LMS helps an individual achieve better learning performance. For last few decades, in relation to information systems, acceptance, adoption satisfaction, system use/intention to use and user performance, have been predominant constructs for measuring IS success [15], [12], [29]. Moreover, previous research suggests that high involvement with the information system provide benefits to individuals [12], [30], [15]. System use refers to the quality, nature and the appropriateness of system use and simply the time spent on system is not an appropriate measure of system use [12]. Many IS success research highlighted the importance of system use as an important measure of IS success [15], [10], [12]. [12] emphasised that the nature of the system uses as a primary determinant of individual or organisational performance. Students perceive LMS use/intention to use based on the value it adds to their learning activities. Thus, according to how they perceive, system usage is determined. However, in most instances LMS is used as the course delivery method and therefore its use is mandatory. According to [10], [12] IS success model, system usage is a direct determinant of individual impact (For example, job performance or quality of work). Thus, the following hypothesis is formulated:

\section{H7: Intention to use LMS has a positive effect on benefits to students.}

\section{E. Student satisfaction affects Benefits to students}

User satisfaction is extensively used in measuring IS success [12], [13]. IS success model [10] suggests that system use and user satisfaction are determinants of individual impact. User satisfaction and system use were the most widely used success measures of information systems [31]. In information systems literature, user satisfaction was identified as an important factor for achieving net benefits [12]. In the e-Learning context, student satisfaction refers to the extent to which LMS meets students' expectations. Researchers who validated [12] IS success model in e-Learning systems success research used 
student learning as one of the measures of net benefits [27], [32]. Learning is arguably the most important outcome or benefit an individual student can obtain through an educational activity, regardless of the method of delivery. [22] established a positive relationship between student satisfaction of an e-Leaning system and student learning. Based on the above justification, the following hypothesis is proposed:

\section{H8: Student satisfaction with LMS has a positive effect on benefits to students.}

\section{METHODOLOGY}

The current study is based on a non-probabilistic sampling method, a convenience sample. The study utilized the quantitative research design. More specifically, data were collected by means of an online questionnaire consisting of 44 questions. The questionnaire used for this study was developed utilizing already validated items that were used in previous studies. The Likert scale on a seven-point scale anchored from 1-Strongly disagree to 7-Strongly agree was used to measure the agreement or the disagreement of the students with the given measurement items. Data were collected from a group of undergraduate students of a leading university in Sri Lanka who are exposed to a blended learning environment with face-to face classroom learning and learning through the LMS. All the respondents were voluntarily participated in the survey. After screening for missing data, 187 usable responses were retained for data analysis. In data analysis, SPSS (Version 23) was used for the demographic data analyses while model analyses were carried out by using PLS-SEM (SmartPLS 3.0).

\section{RESULTS}

Partial Least Squares (PLS) is a second-generation multivariate statistical technique which is superior in terms of prediction and explanatory power [33], [34]. It is a variance based structural equation modelling technique which is more suitable for smaller set of data compared to other techniques [33]. Thus, based on the above facts, PLS was chosen in the current study as the primary data analysis technique. SmartPLS (Version 3.0) was used to test the research model. The measurement model was first evaluated followed by the structural model analysis and the results are as follows.

\section{A. Measurement Model Analysis}

In the measurement model analysis, indicator reliability, internal consistency reliability and construct validity were tested. To measure the indicator reliability, factor loadings were used. According to [35] factor loadings that greater than 0.7 , verifies the indicator reliability. According to Table 1 , in this study all the factor loadings were greater than 0.7 except one construct (SQ6). However, as the factor loading was very close to $0.7,(\mathrm{SQ6}=0.674)$ item was retained.
Table 1:Factor Loadings

\begin{tabular}{|c|c|c|c|c|c|c|}
\hline Measures & IQ & INT & NB & SQ & SERQ & US \\
\hline INT1) & & 0.783 & & & & \\
\hline INT2) & & 0.78 & & & & \\
\hline INT3) & & 0.752 & & & & \\
\hline INT4) & & 0.907 & & & & \\
\hline IQ1) & 0.741 & & & & & \\
\hline IQ2) & 0.826 & & & & & \\
\hline IQ3) & 0.855 & & & & & \\
\hline IQ4) & 0.827 & & & & & \\
\hline IQ5) & 0.857 & & & & & \\
\hline NB1) & & & 0.868 & & & \\
\hline NB2) & & & 0.775 & & & \\
\hline NB3) & & & 0.79 & & & \\
\hline NB4) & & & 0.675 & & & \\
\hline NB5) & & & 0.855 & & & \\
\hline NB6) & & & 0.828 & & & \\
\hline SERQ1) & & & & & 0.845 & \\
\hline SERQ2) & & & & & 0.872 & \\
\hline SERQ3) & & & & & 0.889 & \\
\hline SERQ4) & & & & & 0.889 & \\
\hline SERQ5) & & & & & 0.847 & \\
\hline SQ1) & & & & 0.751 & & \\
\hline SQ2) & & & & 0.741 & & \\
\hline SQ3) & & & & 0.727 & & \\
\hline SQ4) & & & & 0.815 & & \\
\hline SQ5) & & & & 0.724 & & \\
\hline SQ6) & & & & 0.674 & & \\
\hline US1) & & & & & & 0.899 \\
\hline US2) & & & & & & 0.919 \\
\hline US3) & & & & & & 0.92 \\
\hline US4) & & & & & & 0.926 \\
\hline
\end{tabular}

Note: INT= Intention to Use, IQ= Information Quality, NB= Net benefits, SERQ= Service Quality, SQ= System Quality, $\mathrm{US}=$ User Satisfaction

Internal consistency reliability refers to "The degree to which the items on a test jointly measure the same construct" [36]. It can be examined using composite reliability and Cronbach's Alpha values [37]. The threshold value considered for Cronbach's Alpha and composite reliability was 0.7 [37]. As given in Table 2, all the Cronbach alpha values and composite reliability values of constructs fulfilled the requirements which verifies the establishment of the internal consistency reliability.

Construct validity is defined as the degree to which a set of measures precisely represent the concept of interest [37]. Convergent validity and discriminant validity were used to establish the Construct validity. [38] defined convergent validity as "The extent to which a measure correlates positively with alternative measures of the same construct". To measure the convergent validity factor loadings and the AVE values of the constructs were used [39]. As given in Table 2 AVE values of all the constructs of the model were 
above the threshold value, 0.5 [33]. Thus, the convergent validity was established.

Table 2:Internal Consistency Reliability and Convergent Validity of measures

\begin{tabular}{|cccc|}
\hline Constructs & $\begin{array}{c}\text { Cronbach's } \\
\text { Alpha }\end{array}$ & $\begin{array}{c}\text { Composite } \\
\text { Reliability }\end{array}$ & AVE \\
\hline IQ & 0.879 & 0.912 & 0.676 \\
INT & 0.82 & 0.882 & 0.652 \\
NB & 0.887 & 0.914 & 0.642 \\
SQ & 0.835 & 0.879 & 0.547 \\
SERQ & 0.919 & 0.939 & 0.755 \\
\hline
\end{tabular}

US

0.936

0.954

0.839

Discriminant validity refers to "The extent to which a construct is truly distinct from other constructs by empirical standards" [38]. According to Fornell \& Larcker criterion, the AVE of each latent construct needs to be larger than the construct's highest squared correlation with any other latent construct [40]. As given in the Table 3, all the square root values of AVE are greater than the correlation values, thus, established the discriminant validity.

Table 4:Discriminant Validity

\begin{tabular}{|ccccccc|}
\hline Constructs & IQ & INT & NB & SQ & SERQ & US \\
\hline IQ & $\mathbf{0 . 8 2 2}$ & & & & & \\
INT & 0.687 & $\mathbf{0 . 8 0 8}$ & & & & \\
NB & 0.719 & 0.692 & $\mathbf{0 . 8 0 1}$ & & & \\
SQ & 0.718 & 0.614 & 0.615 & $\mathbf{0 . 7 4 0}$ & & \\
SERQ & 0.708 & 0.634 & 0.729 & 0.650 & $\mathbf{0 . 8 6 9}$ & \\
US & 0.737 & 0.748 & 0.777 & 0.632 & 0.632 & $\mathbf{0 . 9 1 6}$ \\
\hline
\end{tabular}

B. Structural Model Analysis

PLS-Structural Equation Modeling (PLS-SEM) approach was used for the structural model analysis. It is a method which maximizes the explained variance of the endogenous latent variables [33]. After testing reliability and validity, SEM focuses on coefficients of determination ( $R 2$ values) and significance of path coefficient [38]. coefficient of determination ( $\mathrm{R} 2$ value) measures the predictive power of the model and as a rule of thumb, $\mathrm{R} 2$ values of $0.75,0.50$, or 0.25 could be described as substantial, moderate, or weak, respectively for endogenous latent variables [33]. In this study, the model explained $52.9 \%$ of variance in intention to use, $57.9 \%$ variance in user satisfaction and $63.2 \%$ of variance in net benefits which can be identified under moderate level. See Fig. 2.

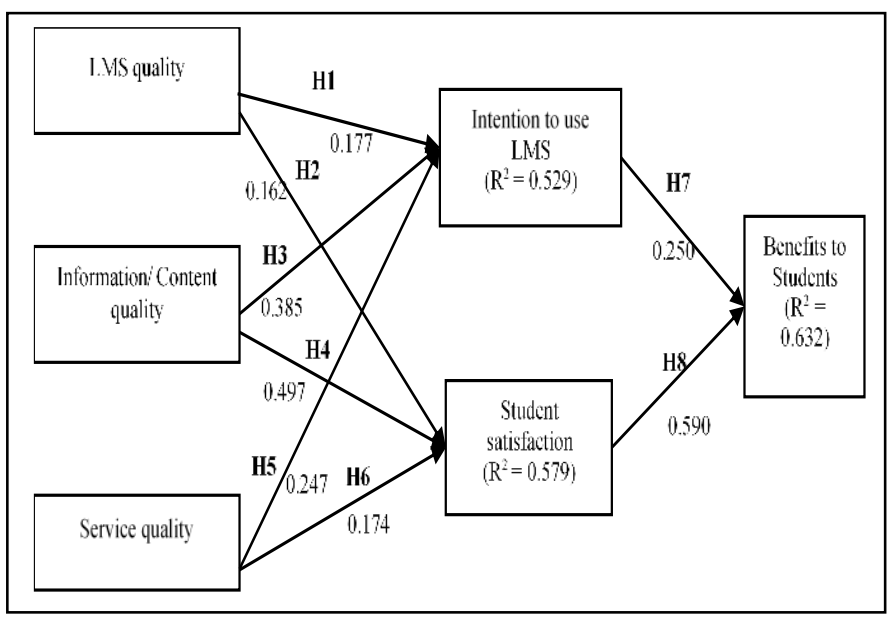

Figure 2: Model with Results

The bootstrapping process in SmartPLS was used for the hypotheses testing. According to [38], 95\% level of confidence is more favorable which emphasizes that $p$ values must be less than 0.05. As given in Table 4, seven hypotheses were supported except one between system quality and user satisfaction.

Table 3:Hypothese Testing

\begin{tabular}{|cccc|}
\hline Hypotheses & $\begin{array}{c}\text { Path } \\
\text { Coefficients }\end{array}$ & $\begin{array}{c}\text { p } \\
\text { Values }\end{array}$ & $\begin{array}{c}\text { Supported/Not } \\
\text { supported }\end{array}$ \\
\hline $\begin{array}{c}\text { System Quality -> } \\
\text { Intention to Use } \\
\text { System Quality -> }\end{array}$ & 0.177 & 0.043 & Supported \\
$\begin{array}{c}\text { User Satisfaction } \\
\text { Information Quality -> } \\
\text { Intention to Use }\end{array}$ & 0.162 & 0.117 & Not Supported \\
$\begin{array}{c}\text { Information Quality -> } \\
\text { User Satisfaction }\end{array}$ & 0.385 & 0.000 & Supported \\
$\begin{array}{c}\text { Service Quality -> } \\
\text { Intention to Use }\end{array}$ & 0.247 & 0.000 & Supported \\
$\begin{array}{c}\text { Service Quality-> } \\
\text { User Satisfaction }\end{array}$ & 0.174 & 0.020 & Supported \\
Intention to Use -> \\
$\quad$ Net Benefits & 0.250 & 0.001 & Supported \\
$\begin{array}{c}\text { User Satisfaction -> } \\
\text { Net Benefits }\end{array}$ & 0.590 & 0.000 & Supported \\
\hline
\end{tabular}

\section{DISCUSSION}

The main purpose of the current study was to examine the determinants of LMS success in a developing country, more specifically in Sri Lanka. DeLone and McLean IS success model (2003) was used. This study has established, both 
theoretically and empirically, the IS success model as a successful theory that can be used in e-Learning contexts (considering e-Learning also as a kind of an information system) to provide a better understanding of the success of eLearning systems. The $R^{2}$ values calculated (variance explained) for each of the constructs are given in Figure 02. The model explained $63 \%$ of the variance in net benefits, $57 \%$ of the variance in student satisfaction, and $53 \%$ of the variance in students' intention to use LMS. [41] suggested that if variance explained is above $10 \%$ as having substantive model explanatory power. As the variance explained is much higher than the threshold given, it indicates that the model has a good fit with a substantial explanatory power.

More specifically, the results of the study provided that intention to use the LMS and student satisfaction as significant determinants of net benefits of LMS. Further, intention to use LMS and student satisfaction were determined by system quality, content/information quality and service quality except for system quality and student satisfaction relationship. Thus, the findings of the study indicate that students as long as perceive the overall quality of the LMS as high tend to use it more. Hence, to get more student involvement with the system, lecturers/instructors should concentrate on improving or maintaining the quality of the system, quality of the content/information, and quality of service provided in relation to LMS to fulfill students' requirements. On the other hand, students are more satisfied when content/information quality and service quality is higher. Since intention to use and student satisfaction both have a significant positive impact on net benefits, it can be concluded that system quality, content/information quality and service quality (except system quality and student satisfaction relationship, where the effect is not significant) as determinants of net benefits of the system indirectly through intention to use and student satisfaction. Thus, it can be concluded that the students are confident with the quality of the LMS, content/information quality and the service quality. Among the effects on student satisfaction, content/information quality had the highest effect than other factors (see Figure 2). This confirmed what previous research found in relation to information quality and student satisfaction relationship in e-Learning contexts [42], [43], [44]. [44] found that information quality is a significant determinant of intention to use in studies on e-learning. The current study provided consistent findings with previous studies, where it uncovered a strong significant positive impact of content/information quality on students' intention to use LMS. In this study system quality is found to be a significant factor affecting intention to use LMS. However, system quality had the least impact on student satisfaction. Thus, hypothesis two (H2) was not supported. A possible justification for this outcome (in relation to hypotheses H2) may be the respondents for this study comprised of a group of students in a blended learning environment and novice to elearning. Thus, they may still prefer face-to-face learning as they are used to it for a long period of time, and therefore, quality of the system may not have much impact on their satisfaction. Further, this may be because they are not yet competent enough to use the full functionality of the system. However, when they become used to technology mediated learning and when they gain experience in using such systems, the situation may change. According to the findings, service quality had significant positive impact on intention to use [45], [44] and student satisfaction [46], [43], [44] where they uncovered that there exist a positive impact of information quality on intention to use and user satisfaction. During the last decade, technology mediated learning, more specifically, LMSs, was used at a greater extent in the tertiary education sector in Sri Lanka. However, it is still at initial stages in the country, and yet a wider scope for advancements in future to transform traditional to online teaching and learning. The findings of this study would provide better insights for the responsible personnel in higher education institutions of how students perceive different success determinants and dimensions, thus, allowing the decision makers to direct their educational technology initiatives in the correct path for better advancements in the future.

\section{IMPLICATIONS AND CONCLUSION}

This study provides several implications for theory and practice. From the theoretical perspective, the important outcome of this study is to provide a better understanding of the determinants of LMS success in Sri Lanka. The study concludes that system quality, content/information quality, service quality play an important role in determining students' intention to use LMS and the importance of content quality and service quality as determinants of student satisfaction with LMS. According to the review of literature use of IS success model (as it is) was limited in e-Learning contexts, though very commonly used in other IS domains. Further, in this study, validating IS success model helped enhance the validity and generalizability of the IS success model by testing the model in a different context and in a different IS domain. This study uncovered the perceptions of students using LMS in their learning, thus providing the policy makers and implementors to better understand student expectations in relation to using LMSs. This help higher education institutions in Sr Lanka to effectively deploy such systems in their institutions which pave the way for them to achieve strategic goals in technology-based education. This study was the first study of its kind in the context of Sri Lankan universities. Thus, this research provides meaningful insights particularly relevant to e-Learning implementors in higher education in Sri Lanka. Further, the results suggest the implementors to improve quality of the content/information, the dimension that had the strongest effect on both student intention to use the LMS and student satisfaction with LMS. 


\section{REFERENCES}

[1] S. Alagarsamy and M. Vijay, "Construction and Validation of the Learning Management System Success Scale in the Higher Education Setting," GATR Glob. J. Bus. Soc. Sci. Rev., vol. 7, no. 2, pp. 139-150, Jun. 2019

[2] J. Gilbert, S. Morton, and J. Rowley, "e-Learning: The student experience,” Br. J. Educ. Technol., vol. 38, no. 4, pp. 560-573, 2007.

[3] S. Ozkan, R. Koseler, and N. Baykal, "Evaluating learning management systems: Adoption of hexagonal e-learning assessment model in higher education | Request PDF." [Online]. Available: https://www.researchgate.net/publication/235263737_Evaluating_learni ng_management_systems_Adoption_of_hexagonal_elearning_assessment_model_in_higher_education. [Accessed: 05-Dec2019].

[4] M. H. Zakaria, J. Watson, and S. L. Edwards, "Investigating the Use of Web 2.0 Technology by Malaysian Students," Multicult. Educ. Technol. J., vol. 4, no. 1, pp. 17-29, 2010.

[5] N. Sayfouri, "Evaluation of the learning management system using students' perceptions," Med. J. Islam. Repub. Iran, vol. 30, p. 460, 2016

[6] B.-C. Lee, J.-O. Yoon, and I. Lee, "Learners' acceptance of e-learning in South Korea: Theories and results," Comput. Educ., vol. 53, no. 4, pp. 1320-1329, Dec. 2009.

[7] J.-K. Lee and W.-K. Lee, "The Relationship of e-Learner's Selfregulatory Efficacy and Perception of e-Learning Environmental Quality," Comput Hum Behav, vol. 24, no. 1, pp. 32-47, Jan. 2008

[8] S. Park, "(PDF) An Analysis of the Technology Acceptance Model in Understanding University Students' Behavioral Intention to Use eLearning." [Online]. Available: https://www.researchgate.net/publication/220374248_An_Analysis_of_t he Technology_Acceptance_Model_in_Understanding_University_Stu dents'_Behavioral_Intention_to_Use_e-Learning. [Accessed: 05-Dec2019].

[9] T. Saarinen, "An expanded instrument for evaluating information system success," Inf. Manage., vol. 31, no. 2, pp. 103-118, Nov. 1996.

[10] W. H. DeLone and E. R. McLean, "Information Systems Success: The Quest for the Dependent Variable," Inf. Syst. Res., vol. 3, no. 1, pp. 6095, Mar. 1992.

[11] M. M. Alfraih and F. S. Alanezi, "Accounting Students' Perceptions of Effective Faculty Attributes," J. Int. Educ. Bus., vol. 9, no. 2, pp. 123 142, 2016.

[12] W. H. DeLone and E. R. McLean, "The DeLone and McLean Model of Information Systems Success: A Ten-Year Update," J. Manag. Inf. Syst., vol. 19, no. 4, pp. 9-30, Apr. 2003.

[13] P.-C. Sun, R. J. Tsai, G. Finger, Y.-Y. Chen, and D. Yeh, "What Drives a Successful E-Learning? An Empirical Investigation of the Critica Factors Influencing Learner Satisfaction," Comput. Educ., vol. 50, no. 4, pp. 1183-1202, May 2008.

[14] A. Rai, S. S. Lang, and R. B. Welker, "Assessing the validity of IS success models: An empirical test and theoretic...," p. 22.

[15] F. D. Davis, "Perceived Usefulness, Perceived Ease of Use, and User Acceptance of Information Technology," MIS Q., vol. 13, pp. 319-340, 1989.

[16] C.-M. Chiu, M.-H. Hsu, S.-Y. Sun, T.-C. Lin, and P.-C. Sun, "Usability, Quality, Value and E-Learning Continuance Decisions," Comput. Educ., vol. 45, no. 4, pp. 399-416, Dec. 2005.

[17] M. P. Menchaca and T. A. Bekele, "Learner and instructor identified success factors in distance education," Distance Educ., vol. 29, no. 3, pp. 231-252, Nov. 2008.

[18] G. Piccoli, R. Ahmed, and B. Ives, "Web-Based Virtual Learning Environments: A Research Framework and a Preliminary Assessment of Effectiveness in Basic IT Skills Training | Request PDF." [Online]. Available: https://www.researchgate.net/publication/220260138_WebBased_Virtual_Learning_Environments_A_Research_Framework_and a_Preliminary_Assessment_of_Effectiveness_in_Basic_IT_Skills_Train ing. [Accessed: 05-Dec-2019].

[19] S. I. Swaid and R. T. Wigand, "Swaid, S.I. and Wigand, R.T. (2009) Measuring the Quality of E-Service Scale Development and Initial Validation. Journal of Electronic Commerce Research, 10, 13. -
References - Scientific Research Publishing." [Online]. Available: https://www.scirp.org/(S(i43dyn45teexjx455qlt3d2q))/reference/Refere ncesPapers.aspx?ReferenceID=2119664. [Accessed: 05-Dec-2019].

[20] T. McGill, V. Hobbs, and J. Klobas, "User Developed Applications and Information Systems Success: A Test of DeLone and McLean's Model," Inf Resour Manage J, vol. 16, no. 1, pp. 24-45, Jan. 2003.

[21] R. Freeze, K. Alshare, and J. Wen, "[PDF] IS Success Model in ELearning Context Based on Students' Perceptions | Semantic Scholar." [Online]. Available: https://www.semanticscholar.org/paper/IS-SuccessModel-in-E-Learning-Context-Based-on-Freeze-

Alshare/5df2e14402d77f1779c3389e1f357fd860ab2e65. [Accessed: 05Dec-2019].

[22] S. Eom, J. Wen, and A. Nicholas, "The Determinants of Students' Perceived Learning Outcomes and Satisfaction in University Online Education: An Empirical Investigation* - Eom - 2006 - Decision Sciences Journal of Innovative Education - Wiley Online Library.' [Online]. https://onlinelibrary.wiley.com/doi/full/10.1111/j.15404609.2006.00114.x. [Accessed: 05-Dec-2019].

[23] M. Masrek, "(PDF) Assessing users' satisfaction with web digital library: the case of Universiti Teknologi MARA." [Online]. Available: https://www.researchgate.net/publication/290519045 Assessing users satisfaction_with_web_digital_library_the_case_of_Universiti_Teknolo gi_MARA. [Accessed: 05-Dec-2019].

[24] T. Ahn, S. Ryu, and I. Han, "The impact of the online and offline features on the user acceptance of Internet shopping malls," Electron. Commer. Res. Appl., vol. 3, no. 4, pp. 405-420, Dec. 2004.

[25] A. Parasuraman, V. A. Zeithaml, and L. L. Berry, "Alternative scales for measuring service quality: A comparative assessment based on psychometric and diagnostic criteria," J. Retail., vol. 70, no. 3, pp. 201230, Sep. 1994

[26] R. T. Cenfetelli, I. Benbasat, and S. Al-Natour, "Addressing the What and How of Online Services: Positioning Supporting-Services Functionality and Service Quality for Business-to-Consumer Success," Inf. Syst. Res., vol. 19, no. 2, pp. 161-181, Jun. 2008.

[27] C. W. Holsapple and A. Lee- Post, "Defining, Assessing, and Promoting E-Learning Success: An Information Systems Perspective*," Decis. Sci. J. Innov. Educ., vol. 4, no. 1, pp. 67-85, 2006.

[28] C.-M. Chiu, C.-S. Chiu, and H.-C. Chang, "Examining the integrated influence of fairness and quality on learners' satisfaction and Webbased learning continuance intention," Inf. Syst. J., vol. 17, no. 3, pp. 271-287, 2007.

[29] R. Prasanna and T. J. Huggins, "Factors Affecting the Acceptance of Information Systems Supporting Emergency Operations Centres,' Comput Hum Behav, vol. 57, no. C, pp. 168-181, Apr. 2016

[30] M. Masrek and I. Samadi, "User engagement in academic web digital library," Int. J. Civ. Eng. Technol. IJCIET, vol. 8, pp. 789-799, Sep. 2017

[31] R. H. Bokhari, "The relationship between system usage and user satisfaction: a meta- analysis," J. Enterp. Inf. Manag., vol. 18, no. 2, pp. 211-234, Apr. 2005.

[32] Y.-S. Wang, H. Y. Wang, and D. Y. Shee, "Measuring e-learning systems success in an organizational context: Scale development and validation," Comput. Hum. Behav., vol. 23, no. 4, pp. 1792-1808, Jul. 2007

[33] J. Hair, C. Ringle, and M. Sarstedt, "PLS-SEM: Indeed a Silver Bullet: Journal of Marketing Theory and Practice: Vol 19, No 2." [Online]. Available: https://www.tandfonline.com/doi/abs/10.2753/MTP10696679190202. [Accessed: 05-Dec-2019].

[34] N. F. Richter, R. R. Sinkovics, C. M. Ringle, and C. Schlägel, "A critical look at the use of SEM in international business research," Int. Mark. Rev., vol. 33, no. 3, pp. 376-404, May 2016

[35] G. A. Marcoulides, Modern Methods for Business Research. Psychology Press, 1998.

[36] R. K. Henson, "Understanding internal consistency reliability estimates: A conceptual primer on coefficient alpha," Meas. Eval. Couns. Dev., vol. 34, no. 3, pp. 177-189, 2001

[37] Hair, Black, Babin, and Anderson, "Hair, Black, Babin \& Anderson, Multivariate Data Analysis, 7th Edition | Pearson." [Online]. Available: https://www.pearson.com/us/higher-education/program/Hair- 
Multivariate-Data-Analysis-7th-Edition/PGM263675.html. [Accessed: 05-Dec-2019].

[38] J. F. Hair, T. M. Hult, C. Ringle, and M. Sarstedt, "2nd Edition: A Primer on Partial Least Squares Structural Equation Modeling (PLSSEM)," pls-sems Webseite! [Online]. Available: http://www.plssem.net/downloads/2st-edition-a-primer-on-pls-sem/. [Accessed: 05Dec-2019].

[39] R. P. Bagozzi, Y. Yi, and L. W. Phillips, "Assessing Construct Validity in Organizational Research," Adm. Sci. Q., vol. 36, no. 3, pp. 421-458, 1991.

[40] C. Fornell and D. F. Larcker, "Evaluating Structural Equation Models with Unobservable Variables and Measurement Error - Claes Fornell, David F. Larcker, 1981." [Online]. Available: https://journals.sagepub.com/doi/abs/10.1177/002224378101800104?jo urnalCode $=$ mrja. [Accessed: 05-Dec-2019].

[41] R. F. Falk and N. B. Miller, A primer for soft modeling. Akron, OH, US: University of Akron Press, 1992.

[42] T. Adeyinka and S. Mutula, "A Proposed Model for Evaluating the Success of WebCT Course Content Management System," Comput Hum Behav, vol. 26, no. 6, pp. 1795-1805, Nov. 2010.

[43] J. C. Roca, C.-M. Chiu, and F. J. Martínez, "Understanding e-learning continuance intention: An extension of the Technology Acceptance Model," Int. J. Hum. -Comput. Stud., vol. 64, no. 8, pp. 683-696.

[44] H. C. Wang and Y. F. Chiu, "Assessing e-learning 2.0 system success," Comput. Educ., vol. 57, no. 2, pp. 1790-1800, Sep. 2011.

[45] Y. M. Cheng, "Effects of quality antecedents on e- learning acceptance | Emerald Insight." [Online]. Available: https://www.emerald.com/insight/content/doi/10.1108/10662241211235 699/full/html. [Accessed: 05-Dec-2019].

[46] P. Poulová and I. Šimonová, "E-learning Reflected in Research Studies in Czech Republic: Comparative Analyses," Procedia - Soc. Behav. Sci., vol. 116, pp. 1298-1304, Feb. 2014. 